Int. J. Dev. Biol. 58: 107-116 (2014)

doi: $10.1387 / \mathrm{ijdb} .130344$ ts

\title{
Uterine glands: biological roles in conceptus implantation, uterine receptivity and decidualization
}

\author{
JUSTYNA FILANT and THOMAS E. SPENCER* \\ Department of Animal Sciences and Center for Reproductive Biology, Washington State University, Pullman, WA, USA
}

\begin{abstract}
All mammalian uteri contain glands in the endometrium that synthesize or transport and secrete substances essential for survival and development of the conceptus (embryo/fetus and associated extraembryonic membranes). This review summarizes information related to the biological roles of uterine glands and their secretions in uterine receptivity, blastocyst/conceptus survival and implantation, and stromal cell decidualization. Studies with the ovine uterine gland knockout (UGKO) model support a primary role for uterine glands and, by inference, their secretions present in uterine luminal fluid histrotroph for conceptus survival and development. In rodents, studies with mutant and progesterone-induced UGKO mice found that uterine glands and their secretions are unequivocally required for establishment of uterine receptivity and blastocyst implantation and also may influence blastocyst trophectoderm activation and stromal cell decidualization in the uterus. Similarly in humans, histotroph from uterine glands appears critical for blastocyst implantation, uterine receptivity, and conceptus nutrition during the first trimester and uterine glands likely have a role in stromal cell decidualization. An increased understanding of uterine gland biology is important for diagnosis, prevention and treatment of fertility problems, particularly infertility and recurrent pregnancy loss, in domestic animals and humans.
\end{abstract}

KEY WORDS: uterus, gland, blastocyst, implantation, decidualization, pregnancy

\section{Introduction}

Although the organogenetic development and differentiation of most female reproductive tract organs are complete at birth, the uterus is not fully developed or differentiated at birth, and establishment of tissue-specific histoarchitecture is only completed postnatally in laboratory rodents, domestic animals, and humans (Bartol et al., 1999, Gray et al., 2001a). The process of postnatal radial patterning morphogenesis establishes the three classic histological elements of the uterine wall, including the: (1) endometrium; (2) myometrium, which consists of an inner circular layer and an outer longitudinal layer of oriented smooth muscle; and (3) perimetrium. Morphogenetic events common to postnatal morphogenesis of uteri include: (1) organization and stratification of endometrial stroma; (2) differentiation and growth of the myometrium; and (3) coordinated development of uterine glands. The glandular epithelium (GE) begins to develop as invaginations of luminal epithelium (LE) that progressively invade the stroma, ultimately resulting in an extensive network of epithelial glands that extend to the myometrium. Several recent reviews focus on the biology of uterine gland differentiation and development (Cooke et al., 2013, Spencer et al., 2012, Spencer et al., 2005, Zhang et al., 2013). The purpose here is to provide an overview of how uterine glands and histotroph have established or potential biological roles in conceptus survival and development, uterine receptivity, blastocyst implantation and stromal cell decidualization.

\section{Uterine glands: a historical perspective}

While empirical evidence that uterine glands are required to support pregnancy was provided only recently (Cooke et al., 2012, Filant and Spencer, 2013b, Gray et al., 2001c), the idea that uterine secretions are essential to the success of pregnancy developed over the last 500 years (see (Cooke et al., 2013)). Hippocrates (460-370 BC) and his students argued that the fetus was nourished per os by sucking on maternal cotyledons or 'uterine paps'. For centuries thereafter it was envisioned that, as the uterus grew with pregnancy, pressure of the reproductive tract

Abbreviations used in this paper: AA, amino acids; GE, glandular epithelium; LE, luminal epithelium; UGKO, uterine gland knockout; ULF, uterine luminal fluid.

\footnotetext{
*Address correspondence to: Thomas E. Spencer. Department of Animal Science, 1815 Ferdinand's Lane, VRB 175, Washington State University, Pullman, Washington 99164-7620, USA.Tel: +1-509-335-4124. E-mail: thomas.spencer@wsu.edu
}

Final, author-corrected PDF published online: 8 July 2014.

ISSN: Online 1696-3547, Print 0214-6282 
against the breasts would result in milk being pumped directly into uterine arteries. Aristotle (384-322 BC) argued against this notion on anatomical grounds; however, drawings by both Leonardo da Vinci (1452-1519 AD) and Andreas Vesalius (1514-1564 AD) still showed arteries connecting the breasts and reproductive tract. William Harvey (1578-1657 AD) was among the first to recognize conceptus nourishment by substances within the uterus ('vicar of the breasts'), much as the neonate is nourished by milk. Walter Needham (1631-1691) refuted Hippocratic theory, arguing that the substance that could be squeezed from uterine tissues was distinct from lymph and important in fetal nutrition. Needham is credited with naming this substance 'uterine milk' (Amoroso, 1952, Needham, 1959). In the late $19^{\text {th }}$ century, von Hoffman observed, relative to the human placenta, that "fetal villi in the placenta do not float naked in the maternal blood, but are surrounded by cells whose function it is to secrete a special fluid serving for nutrition of the fetus, and called uterine milk" (von Hoffman, 1884). According to Amoroso (Amoroso, 1952), the term embryotrophe, coined in the late $19^{\text {th }}$ century, was used to describe all available material supplied to the conceptus in utero. In the early $20^{\text {th }}$ century, the terms hemotroph and histotroph were coined to describe those substances essential for support of conceptus and fetal development supplied via the uterus either: (1) directly from blood (hemotroph); or (2) from the uterine endometrium (histotroph) (Bazer, 1975). Direct evidence of the essential nature of histotroph came with the demonstration in sheep and mice that uterine glands are unequivocally required for female fertility (Cooke et al., 2012, Filant and Spencer, 2013b, Gray et al., 2001c).

\section{Uterine glands and early pregnancy in sheep}

Ruminants (cattle, goats, and sheep) have a bicornuate uterus with a small common corpus and single cervix (Spencer et al., 2012). The endometrium in adult sheep and cattle has a large number of aglandular caruncular areas, which are dense stromal areas covered by a simple LE, and intercaruncular areas. The intercaruncular areas of the endometrium contain many hundreds of glands in a cross-section of the uterine wall. Caruncular areas are the sites of superficial implantation and placentation. In synepitheliochorial placentation found in ruminants, fusion of placental cotyledons with endometrial caruncles forms placentomes, which serve a primary role in fetal-maternal gas exchange and derivation of nutrients by the placenta for hemotrophic nutrition of the fetus. Of note, uterine glands undergo hyperplasia and continue to function throughout gestation in domestic animals for histotrophic nutrition of the fetus.

\section{Early pregnancy events}

Establishment of pregnancy in domestic ruminants (i.e., sheep, cattle, goats) begins at the conceptus stage and includes pregnancy recognition signaling, implantation, and placentation (Spencer et al., 2004, Spencer et al., 2008). The morula-stage embryo enters the uterus on days 4 to 6 post-mating and then forms a blastocyst that contains an inner cell mass and a blastocoele or central cavity surrounded by a monolayer of trophectoderm. After hatching from the zona pellucida (days 8 to 10), the hatched blastocyst slowly grows into a tubular or ovoid form and is then termed a conceptus (embryo/fetus and associated extraembryonic membranes) (Guillomot, 1995, Hue et al., 2012). The ovoid conceptus of about $1 \mathrm{~cm}$ on day 11 begins to elongate on day 12 and forms a filamentous conceptus of 10 to $15 \mathrm{~cm}$ or more in length that occupies the entire length of the uterine horn ipsilateral to the corpus luteum. After day 16 , the elongating conceptus begins the process of implantation and placentation. Conceptus elongation involves exponential increases in length and weight of the trophectoderm and onset of extraembryonic membrane differentiation, including gastrulation of the embryo and formation of the yolk sac and allantois that are vital for embryonic survival and formation of a functional placenta.

\section{Uterine gland knockout (UGKO) sheep model}

Uterine gland differentiation and development (or adenogenesis) in sheep is a uniquely postnatal event (Bartol et al., 1999, Gray et al., 2001a, Spencer et al., 2012). Work involving rodents (Bigsby and Cunha, 1985, Ogasawara et al., 1983) and sheep (Bartol et al., 1988a, Bartol et al., 1988b) established that onset of adenogenesis was independent of the ovary or steroid hormones and progestins could suppress uterine epithelial cell proliferation. Since uterine tissues are steroid responsive perinatally, it was hypothesized that birth provides an endocrine cue for onset of uterine gland genesis by delivering uterine tissues from an anti-proliferative fetal endocrine environment. This hypothesis was tested by Frank "Skip" Bartol who exposed ewe lambs to norgestomet, a non-metabolizable and potent synthetic progestin, from birth to postnatal day 13, which inhibited uterine adenogenesis (Bartol et al., 1988a). Removal of the progestin block to adenogenesis on postnatal day 13 permitted glands to develop by postnatal day 26; however, these glands were underdeveloped and histologically abnormal. This original observation served as the foundation for the idea that prolonged exposure of neonatal ewes to progestins during adenogenesis could permanently inhibit uterine gland differentiation, thereby producing a uterine gland knockout (UGKO) phenotype in adults (Bartol et al., 1999). Subsequently, exposure of neonatal ewes to norgestomet from birth to 8 weeks of life was used to permanently ablate the postnatal differentiation of uterine glands, resulting in a UGKO phenotype in the adult (Gray et al., 2000a, Gray etal., 2001b, Gray et al., 2002). Exposure of neonatal ewes to norgestomet did not affect development or function of brain, hypothalamic-pituitaryovarian axis, ovary, or other Müllerian duct derivatives, including oviduct, cervix and vagina (Gray et al., 2001b, Gray et al., 2000b). Of note, the uteri of adult UGKO ewes were devoid of glands and lacked intercaruncular endometrial areas characteristic of normal ewes with reduced amount of LE (Gray et al., 2001b).

The infertility of UGKO sheep revealed an essential role for uterine glands and their secretions in conceptus survival and development during early pregnancy. Indeed, adult UGKO ewes were completely infertile and exhibited recurrent pregnancy loss (Gray et al., 2001b, Gray et al., 2002, Gray et al., 2001c). Morphologically normal blastocysts were present in UGKO ewes after mating on day 9 , but conceptuses were absent or severely growth-retarded by day 12 or 14 . Of note, the majority of natural pregnancy losses in domestic ruminants occur during the first two weeks of pregnancy (Diskin and Morris, 2008).

\section{Glandular secretions and uterine function in sheep}

Although blastocysts can develop entirely in vitro, the overall success of this process and quality of the blastocysts is markedly lower than for those developed in vivo, and they must be transferred into a receptive uterus for growth and development into an elongated, filamentous conceptus. The lack of conceptus elonga- 
tion in UGKO ewes is presumably due to the absence of specific secretions that emanate from the glands of the uterus (Gray et al., 2001a, Gray et al., 2002). Histotroph in the uterine luminal fluid (ULF) of sheep and other ruminants is a complex and rather undefined mixture of ions, AA, carbohydrates, proteins, lipids, and other substances that are selectively transported into the uterine lumen by the endometrial epithelia from serum transudate as well as specific secretory products encoded by genes expressed in the LE and GE (see (Bazer, 1975, Gray et al., 2001a, Spencer et al., 2008)). Available evidence supports the idea that ovarian progesterone induces expression of a number of genes, specifically in the endometrial LE and/or GE, that are then further stimulated by factors from the conceptus (interferon tau, prostaglandins and cortisol) as well as the endometrium itself (prostaglandins, cortisol) (see (Bazer et al., 2010, Dorniak et al., 2013) for review). The genes and functions regulated by these hormones and factors in the endometrial epithelia trigger specific changes in the intrauterine histotrophic milieu that are necessary for conceptus elongation.

Given the recurrent pregnancy loss phenotype of the UGKO ewe, the secretions produced by the uterine glands are of primary import for conceptus elongation; however, knowledge of the GE transcriptome and secrotome remains incomplete. A mass spectrometry experiment found that a large number of proteins are present in the ULF of day 16 cyclic and early pregnant sheep (Koch et al., 2010). The uterine glands of early pregnant sheep express genes that encode for secreted factors (CTGF, GRP, WNT11), AA transporters (SLC1A1, SLC1A4, SLC1A5, SLC7A1, SLC7A2, SLC7A5, SLC7A8, SLC43A2), glucose transporters (SLC2A1, SLC2A5, SLC2A12, SLC5A1, SLC5A11), secreted migration and attachment factors (LGALS15, SPP1), a regulator of calcium/phosphate homeostasis (stanniocalcin one or STC1), secreted peptidases (CTSH, CTSL, CTSS, CTSZ), secreted protease inhibitors (CST3, CST6), and an immunomodulatory factor (SERPINA14; also known as uterine milk protein or uterine serpin). As in mice and humans, some of those genes are also expressed in the LE. Those genes alter the intrauterine milieu or histotroph, such as increasing select AA, glucose, cytokines and growth factors, to support blastocyst survival and growth into an ovoid conceptus and elongation to form a filamentous conceptus

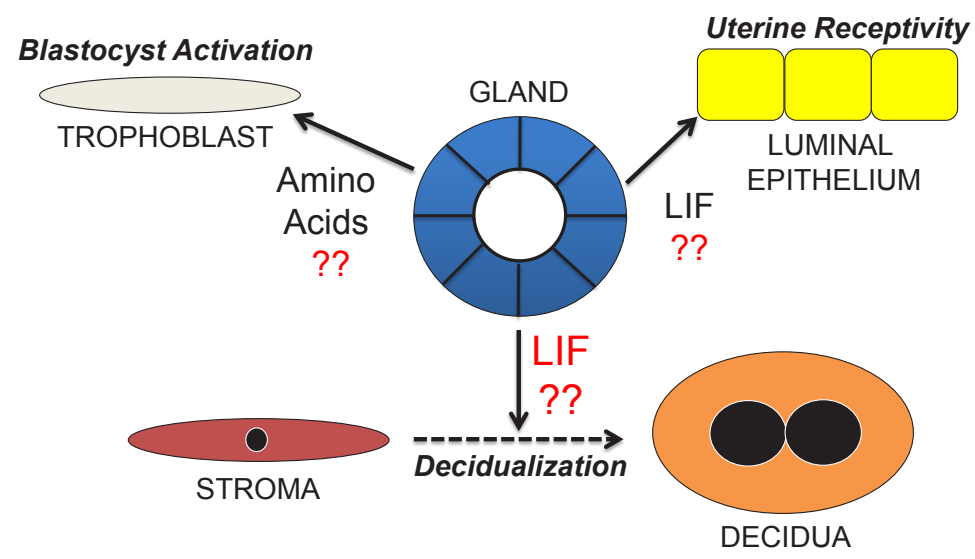

Fig. 1. Hypothesis of the biological roles of uterine glands in blastocyst activation, uterine receptivity to blastocyst implantation, and stromal cell decidualization during pregnancy in mice. See text for detailed description of hypotheses and supporting data. in sheep and cattle (see (Bazer et al., 2010, Dorniak et al., 2013, Forde and Lonergan, 2012, Spencer et al., 2008)).

In sheep, the uterine glands undergo a program of hyperplasia followed by hypertrophy that appears to be dependent on temporal and spatial actions of hormones from the ovary (progesterone) and placenta (placental lactogen and growth hormone) (Bazer et al., 2010, Gray et al., 2001a). Uterine gland morphogenesis during pregnancy allows for the endometrium to increase output of secretory proteins that are transported to the fetus by specialized areas of the placenta termed areolae, which provide histotrophic nutrition to the fetus throughout pregnancy. Similarities exist among other domestic animals (cattle, goats, pigs) as well as humans during the first trimester of pregnancy (Burton et al., 2011).

\section{Uterine glands and pregnancy in mice}

Laboratory rodents (mouse and rat) have a long duplex uterus with a dual cervix (Spencer et al., 2012). The endometrium of the adult rodent uterus consists of a simple columnar LE surrounded by stromal cells containing slightly coiled glands lined by simple cuboidal GE cells. The endometrium typically contains only 10 to 20 glands in a cross-section of the uterine wall, and they are predominantly found in the antimesometrial area of the uterus and not tightly coiled or branched as found in the uterus of humans and domestic animals.

\section{Early pregnancy events in mice}

In rodents, blastocyst implantation involves trophectoderm apposition, attachment, adhesion to the LE followed by penetration and growth of the trophectoderm into the decidualizing stroma (see (Cha et al., 2012, Ramathal et al., 2010, Wang and Dey, 2006, Wetendorf and DeMayo, 2012, Zhang et al., 2013)). This complex process requires dialogue between an implantation-competent blastocyst and a receptive uterus. Dynamic changes in ovarian estrogen and progesterone secretion regulate endometrial function and blastocyst implantation. In mice, the endometrium becomes receptive to blastocyst implantation on day 3.5 of pregnancy or pseudopregnancy (day $0.5=$ morning of a post-coital vaginal plug observation), but it is non-receptive by the afternoon of day 4.5.

The implantation process is initiated by blastocyst attachment to the receptive LE that occurs at midnight on day 3.5. Recent evidence suggests that there are two separate uterine signals regulating blastocyst implantation, one that primes the trophectoderm for attachment to the LE and another that initiates its motility, but the nature of those signals are not well defined (Gonzalez et al., 2012). By day 5.5, the LE cells lining the implantation chamber and near the blastocyst undergo apoptosis allowing the motile trophectoderm to come into contact with stromal cells that are differentiating into decidual cells in a process that involves endoreduplication. Decidualization is required for successful pregnancy and important for implantation of the blastocyst and formation of a functional placenta.

\section{Mouse gene knockouts affecting uterine adenogenesis or gland function \\ Uterine glands have been known to be essential for blasto-} cyst implantation in rodents for the past 20 years. In the early 1990s, the work of Colin Stewart established that leukemia 
TABLE 1

\section{GENES EXPRESSED IN THE GLANDULAR EPITHELIA OF THE MOUSE UTERUS}

\begin{tabular}{|c|c|c|c|c|}
\hline Symbol & Name & Expression $^{1}$ & Null/Conditional Phenotype ${ }^{2}$ & Reference \\
\hline Cxcl15 & chemokine (C-X-C motif) ligand 15 & GE, LE & Viable and fertile & (Chen et al., 2001, Schmitz et al., 2007) \\
\hline Fnbp1 & formin binding protein 1 & GE (GD4-5) & $N / A$ & (Niklaus and Pollard, 2006) \\
\hline Foxa2 & forkhead box A2 & GE (neonatal and adult) & Embryonic lethal, Implantation defect (conditional) & (Ang and Rossant, 1994, Jeong et al., 2010) \\
\hline Gulo & gulonolactone (L-) oxidase & GE $>$ LE (GD4-5) & Viable and fertile & (Maeda et al., 2000, Niklaus and Pollard, 2006) \\
\hline $116 s t$ & interleukin 6 signal transducer & $\begin{array}{l}\text { GE (GD3-5) } \\
\text { Decidua (GD7) }\end{array}$ & Viable and fertile & (Ni et al., 2002, Yoshida et al., 1996) \\
\hline Lif & leukemia inhibitory factor & GE $>>$ Stroma (GD4) & Implantation defect & (Stewart et al., 1992) \\
\hline Lyz2 & lysozyme 2 & Stroma, GE (GD3-5) & Viable and fertile (knock-in) & (Clausen et al., 1999, Niklaus and Pollard, 2006) \\
\hline Prss28 & protease, serine, 28 & GE (GD5-8) & $\mathrm{N} / \mathrm{A}$ & (O'Sullivan et al., 2002) \\
\hline Prss29 & protease, serine, 29 & GE (GD5-9) & $N / A$ & (O'Sullivan et al., 2001) \\
\hline Sh3tc2 & SH3 domain and tetratricopeptide repeats 2 & GE (GD4-5) & Viable and fertile & (Arnaud et al., 2009, Niklaus and Pollard, 2006) \\
\hline Slc23a2 & $\begin{array}{l}\text { solute carrier family } 23 \text { (nucleobase } \\
\text { transporters), member } 2\end{array}$ & GE & Postnatal lethal & (Niklaus and Pollard, 2006, Sotiriou et al., 2002) \\
\hline Spink3 & serine peptidase inhibitor, Kazal type 3 & GE (onset GD4) & Postnatal lethal & (Chen et al., 2010, Ohmuraya et al., 2005) \\
\hline Sult1d1 & sulfotransferase family $1 \mathrm{D}$, member 1 & GE >>LE (GD3-4) & $N / A$ & (Niklaus and Pollard, 2006) \\
\hline Ttr & transthyretin & GE only (peaks on GD4) & Viable and fertile & (Diao et al., 2010, Episkopou et al., 1993) \\
\hline
\end{tabular}

${ }^{1} \mathrm{GD}$, gestational day; GE, glandular epithelium; LE, luminal epithelium. ${ }^{2} \mathrm{~N} / \mathrm{A}$, not available

inhibitory factor (LIF) is expressed specifically by the glands of the mouse uterus in response to the nidatory surge of estrogen from the ovary (Bhatt et al., 1991). Subsequently, LIF was found to be essential for blastocyst implantation in mice, as Lif null mice were infertile due to a failure of blastocyst implantation (Stewart et al., 1992). Recent studies found that a number of knockout (lymphoid enhancer factor 1 or Lef1) and conditional knockout mice [catenin (cadherin associated protein), beta 1 or Ctnnb1; forkhead box A2 or Foxa2, wingless-related MMTV integration site 4 or Wnt4; and Wnt7a] lack glands in the adult uterus (Dunlap et al., 2011, Franco et al., 2011, Franco et al., 2010, Jeong et al., 2010, Jeong et al., 2009, Shelton et al., 2012). Many of those mice exhibit defects in blastocyst implantation and uterine decidualization and thus fertility, which can be attributed to the absence of LIF and other uterine gland-derived factors.

\section{Progesterone effects on uterine epithelial proliferation: a tool to regulate adenogenesis and create uterine gland knockout (PUGKO) mice}

The uterine epithelium in mice, rats, dogs and other species proliferates rapidly during the neonatal period (Bigsby and Cunha, 1985; Cooke et al., 2012b). In mice, uterine epithelial proliferation in the neonate is almost completely blocked by progesterone (Bigsby and Cunha, 1985), just as progesterone abolishes epithelial proliferation induced by estrogen in ovariectomized mice (Martin and Finn, 1971). Proliferation of the uterine epithelium is important for gland development, such as budding differentiation of GE from the LE and growth into the stroma of nascent uterine glands. In the neonate, the onset of adenogenesis was found to be ovary-, adrenal- and steroid-independent, and both progestins and glucocorticoids could suppress uterine epithelial proliferation in rodents (Bigsby and Cunha, 1985, Ogasawara et al., 1983). Subsequently, Paul Cooke found that progesterone treatment could be used to inhibit uterine adenogenesis in neonatal mice, resulting in an UGKO phenotype in the adult (Cooke et al., 2012). Treatment of C57BL/6 mice with progesterone from postnatal days 2 to 10 altered expression of morphoregulatory genes, including upregulation of indian hedgehog (Ihh), and inhibited epithelial cell proliferation, leading to a disruption of uterine gland development in the neonate (Cooke et al., 2012, Filant et al., 2012). The resulting adult UGKO mice cycled normally but were infertile.

Next, progesterone-induced UGKO (PUGKO) mice were used to investigate the biological role of uterine glands in blastocyst implantation and stromal cell decidualization (Filant and Spencer, 2013b). Histological assessment of PUGKO uteri on day 5.5 and 8.5 post-mating found a hatched blastocyst apposed to an intact LE without evidence of implantation or stromal cell decidualization. Expression of several implantation-related factors, including Lif, were absent in the PUGKO uterus, whereas expression of steroid hormone receptors and their regulated genes were not different. The defect in blastocyst implantation in PUGKO mice is likely due to inadequate uterine receptivity and/or blastocyst activation (trophectoderm attachment and motility).

\section{Uterine gland secretions in mice}

Available evidence supports the hypothesis that uterine glands and, by inference, their paracrine-acting secretions have important biological roles in blastocyst implantation, establishment of uterine receptivity, and stromal cell decidualization. Available data indicate that the ULF contains AA, ions, carbohydrates (glucose, lactate, pyruvate), lipids, and proteins (cytokines, enzymes, hormones, growth factors, proteases and their inhibitors, transporters, etc.). Carbohydrates and 19 AA were measured in ULF of mice at estrus (Harris et al., 2005), but no data is available for nutrients in the ULF of the peri-implantation mouse uterus. In fact, LIF has never been documented as present in the ULF of mice.

A number of candidate gene profiling experiments and several microarray studies support the idea that the LE and GE have a distinct molecular signature and that they act differentially and synergistically to establish uterine receptivity and govern trophectoderm attachment and motility for blastocyst implantation and influence stromal cell decidualization (Cha et al., 2012, Evans et al., 2012, Filant et al., 2013, Filant and Spencer, 2013a, Niklaus and Pollard, 2006, Wang and Dey, 2006, Wetendorf and DeMayo, 2012, Zhang et al., 2013). The LE has genes that are solely expressed at peri-implantation stages (Areg, Calb1, Hdc, Hegf1, Irg1, Ptgs2) as well as the GE (Calca, Lif, II6st) (Tables 1 and 2). Both epithelial cell types can uniquely express certain genes, while other genes 
appear to be coordinately expressed (Cdh1, Ihh, KIf5, Msx1/Msx2, Ptgs 1) in both LE and GE (Table 2). Further, genes are also down regulated in either or both epithelial cell types during the receptive window such as Muc1 and Pgr. In adult rodents, blastocyst implantation defects arise from the loss of genes expressed specifically in the GE [LIF and calcitonin/calcitonin-related polypeptide, alpha (CALCA) (Stewart et al., 1992, Zhu et al., 1998)] as well as those in the LE and GE (i.e., Ihh, KIf5, Msx1/Msx2) (Daikoku et al., 2011, Lee et al., 2006, Wang and Dey, 2006) and LE and stroma (i.e., Ptgs2) (Lim et al., 1999, Lim et al., 1997). Of particular note, very few studies have evaluated the substances present in the ULF of mice (Daikoku et al., 2005, Gonzalez et al., 2012, Harris et al., 2005). Given the cellular complexity of the uterus, analysis of the entire uterine transcriptome is not entirely advantageous given the preponderance of stroma and myometrium relative to the endometrial epithelia. Niklaus and Pollard (Niklaus and Pollard, 2006) and Filant and coworkers (Filant et al., 2013, Filant and Spencer, 2013a) have used laser-capture microdissection (LCM) and microarray technology to define the epithelial transcriptome of the peri-implantation mouse uterus. In those studies, LE-expressed genes were enriched for metabolic processes and steroid biosynthesis, whereas retinoid signaling, tight junction, extracellular matrix, and regulation of kinase activity were enriched in the GE. The transcriptome differences in the epithelia support the idea that each cell type has unique genetic signatures that dictate their differential and synergistic function in the uterus. The candidate genes and regulatory networks identified in those studies provide a framework to discover new mechanisms regulating epithelial function, uterine receptivity and blastocyst implantation in early pregnancy (Filant et al., 2013, Filant and Spencer, 2013a, Niklaus and Pollard, 2006).

\section{Biological role of uterine glands and their secretions in implantation and decidualization in mice}

\section{Blastocyst activation}

While progress has been made in understanding the regulation of uterine receptivity, the process of blastocyst activation itself remains poorly understood (Gonzalez et al., 2012). Previous work indicates that AA play an important role in blastocyst activation (see (Martin et al., 2003) for review). Mouse embryos cultivated in vitro require a specific and defined culture medium containing $A A$. This embryonic requirement for AA is not simply nutritive, as AA exposure induces trophectoderm motility through activation of mammalian target of rapamycin (mTOR)-dependent signal transduction cascades only after the embryo has reached the early blastocyst stage (Martin et al., 2003). A short pulse (4-8 h) of AA exposure is sufficient to induce motility in the trophectoderm of the early blastocyst, leading to trophoblast outgrowth in an in vitro model of in vivo implantation behavior. The requirement for $A A$ at this stage acts as a developmental checkpoint; when cultured in vitro without AA supplementation, blastocysts remain in a quiescent state, from which trophoblast motility can be induced at any time by adding AA to the culture medium. Once induced, the effect of AA is not reversible, as removing $A A$ will not then switch embryos back to a quiescent state. A recent study found that leucine and arginine, and in particular, uptake of leucine through the SLC6A14AA transporter, are each required individually and together are sufficient to induce blastocyst activation (Gonzalez et al., 2012). Blastocyst activation in vivo is accompanied by changes in mTOR localization, and these changes occur on day 4.5 of gestation, after the onset of embryo attachment, suggesting that there are two separate signals from the uterus regulating the phases of implantation. Although little is known about the actual composition of mouse ULF in terms of nutrients, recent transcriptional profiling experiments indicate that the uterine LE and GE of the peri-implantation mouse uterus differentially express a number of transporters for AA and glucose (Filant et al., 2013, Filant and Spencer, 2013a).

\section{Blastocyst implantation and stromal cell decidualization}

In both humans and rodents, uterine glands and their secretions have been hypothesized to play important roles in blastocyst implantation and uterine stromal cell decidualization in mice and humans (Burton et al., 2007, Burton et al., 2011, Cha et al., 2012, Hannan et al., 2010, Salamonsen et al., 2007, Zhang et al., 2013). Results with the aglandular PUGKO mouse model, along with those from conditional Foxa2 mutant mice that have much reduced uterine glands (Jeong et al., 2010) and Lif null mice (Stewart et al., 1992), strongly support that hypothesis.

\section{Blastocyst implantation}

Many factors and pathways necessary for implantation have

TABLE 2

\section{GENES EXPRESSED IN THE LUMINAL (LE) AND GLANDULAR EPITHELIA (GE) OF THE MOUSE UTERUS}

\begin{tabular}{|c|c|c|c|c|}
\hline Symbol & Name & Expression $^{1}$ & Null/Conditional Phenotype & Reference \\
\hline Cdh1 & E-cadherin & LE and GE (GD1-4), stroma (GD5-8) & $\begin{array}{l}\text { Embryonic lethal, } \\
\text { Implantation defect (conditional) }\end{array}$ & (Paria et al., 1999, Reardon et al., 2012) \\
\hline Clca3 & chloride channel calcium activated 3 & LE and GE (peaks on GD1) & Viable and fertile & (Jeong et al., 2006, Robichaud et al., 2005) \\
\hline Ihh & Indian Hedgehog & LE and GE (peaks on GD3-4) & $\begin{array}{l}\text { Embryonic lethal, } \\
\text { Implantation defect (conditional) }\end{array}$ & (Lee et al., 2006) \\
\hline KIf5 & Kruppel-like factor 5 & $\begin{array}{l}\text { LE and GE (GD1-5) } \\
\text { Decidua (GD5-8) }\end{array}$ & $\begin{array}{l}\text { Embryonic lethal, } \\
\text { Implantation defect (conditional) }\end{array}$ & (Sun et al., 2012) \\
\hline Ltf & lactotransferrin & LE and GE (GD1-2) & Viable and fertile & (McMaster et al., 1992, Ward et al., 2003) \\
\hline Msx1 & homeobox, msh-like 1 & LE and GE (peaks on GD4 and declines) & $\begin{array}{l}\text { Embryonic lethal, } \\
\text { Subfertile (conditional) }\end{array}$ & Daikoku 2011 \\
\hline Msx2 & homeobox, msh-like 2 & LE and GE (peaks on GD4) & $\begin{array}{l}\text { Viable and fertile, } \\
\text { Infertile (double conditional) }\end{array}$ & (Daikoku et al., 2011, Satokata et al., 2000) \\
\hline Ptgs 1 & Prostaglandin-endoperoxide synthase 1 & LE and GE (peaks on GD4) & Viable, delayed parturition & (Chakraborty et al., 1996, Gross et al., 1998) \\
\hline Tro & Trophinin & LE and GE (peaks between GD4 and 6) & Viable and fertile & (Suzuki et al., 2000) \\
\hline
\end{tabular}

${ }^{1} \mathrm{GD}$, gestational day; GE, glandular epithelium; LE, luminal epithelium 
been identified in mice (see (Cha etal., 2012, Ramathal et al., 2010, Wang and Dey, 2006, Wetendorf and DeMayo, 2012, Zhang et al., 2013)). Of particular note, Lif null mice exhibit defects in blastocyst implantation (Stewart et al., 1992). In mice, LIF is induced in the uterine glands in response to the surge of nidatory estrogen on the morning of implantation (Bhatt et al., 1991, Chen et al., 2000) and is also expressed in the subluminal stroma at the implantation site (Song et al., 2000). It is critical for blastocyst implantation (Bhatt et al., 1991, Stewart et al., 1992) and has pleiotropic effects on both uterine epithelium and stroma (Chen et al., 2000). The absence of uterine glands and their essential secreted factors, including LIF and other factors, is hypothesized to underlie the blastocyst implantation failure observed in the uteri of PUGKO mice. Although LIF has a well-recognized role to establish receptivity of the LE for implantation, the role of many other genes expressed in the uterine glands has not been established (Tables 1 and 2). Recent transcriptional profiling experiments indicate that the glands of the day 2.5 and 3.5 pseudopregnant mouse uterus express many genes that encode for enzymes, transporters or secreted proteins that could regulate blastocyst implantation by modifying the ULF (Filant et al., 2013, Filant and Spencer, 2013a).

\section{Uterine decidualization}

The concept that uterine glands secreted paracrine-acting factors into the stroma to promote decidualization is a relatively new concept based on mouse models that lack uterine glands. As expected due to a defect in blastocyst implantation, no evidence of stromal cell decidualization was found in the PUGKO mouse uterus on day 5.5 post-mating (Filant and Spencer, 2013b). Thus, an artificial model of decidualization was used that involves ovariectomy, hormone replacement and intrauterine administration of oil as a deciduogenic stimulus (Filant and Spencer, 2013b). Using that artificial model, the PUGKO mice exhibited a distinct lack of uterine stromal cell decidualization. Interestingly, LIF can substitute for nidatory estrogen at inducing both implantation and decidualization in hormonally prepared, ovariectomized bred mice that that have glands in their uterus (Chen et al., 2000). However, intrauterine LIF failed to rescue decidualization in ovariectomized PUGKO mice that lack uterine glands (Filant and Spencer, 2013b). Similarly, mice that have a conditional ablation of Foxa2 have a uterus with much reduced numbers of glands and exhibit severe defects in blastocyst implantation as well as stromal cell decidualization using an artificial model (Jeong et al., 2010). Similarly, the uterus of conditional Wnt4 ablated mice also lack uterine glands and have a severely impaired artificial decidual response (Franco et al., 2011). However, the identities of uterine gland-derived factors that regulate stromal cell decidualization are not known, but one candidate is SPINK3 (serine peptidase inhibitor, Kazal type 3). Although Spink3 mRNA is expressed only in the GE of the mouse uterus, SPINK3 protein was detected in the LE and decidual cells as well as uterine glands (Chen et al., 2010). That finding suggests that SPINK3 is secreted in both an apical and basal manner, as found for many other proteins secreted by polarized epithelia. Further, the LE and presumably factors it secretes upon LIF stimulation also has a role in stromal cell decidualization (Lejeune et al., 1981). Thus, paracrine crosstalk between the GE and stroma, LE and stroma as well as exocrine crosstalk between the GE and LE and perhaps GE and trophectoderm may be necessary for optimal uterine decidualization.
In women, the LE and GE maximally express LIF during the midsecretory phase of the menstrual cycle, the period during which the uterus is receptive to an implanting blastocyst (Paiva et al., 2009). A number of studies have found that locally and temporally produced products of the endometrium, such as cytokines and growth factors [interleukin-11 (IL11), relaxin, prostaglandin E2 (PGE2), activin A, corticotrophin-releasing hormone $(\mathrm{CRH})$, and $\mathrm{LIF}]$, enhance in vitro progesterone-induced decidualization of endometrial stromal cells sourced from humans and/or mice (Dimitriadis et al., 2005, Shuya et al., 2011). Thus, paracrine factors from the endometrium and/or embryo enhance decidualization induced in endometrial stromal cells by ovarian progesterone (Bany and Cross, 2006, Cha et al., 2012, Dimitriadis et al., 2005, Kashiwagi et al., 2007). Indeed, recent transcriptional profiling experiments indicate that the glands of the day 2.5 and 3.5 pseudopregnant mouse uterus express many genes that encode for enzymes, transporters or secreted proteins that could regulate stromal cell decidualization in a paracrine manner (Filant et al., 2013, Filant and Spencer, 2013a).

\section{Uterine glands and pregnancy in humans}

Humans have a simplex uterus consisting of a single uterine body (Spencer et al., 2012). The endometrium is lined by a simple LE and contains tubular glands that radiate through endometrial stroma toward the myometrium. Adult human and primate endometria are divided into two functional layers, the upper stratum functionalis containing glands surrounded by loose stroma, and the lower stratum basalis consisting of branched coiled glands and dense stroma. The endometrial functionalis is lost during menses. Histologically, the basalis includes a zone that contains loose stroma and bodies of endometrial glands, and another zone where endometrial glands terminate and endometrial progenitor and stem cells reside. The endometrial basalis is organizationally and functionally dynamic but structurally stable and is not eroded during menstruation or following gestation. This tissue is the germinal compartment of the endometrium in menstruating primates including women, providing stem cells from which the functionalis regenerates after each cycle or following gestation. Although initiated fetally, human uterine gland proliferation is completed postnatally, similar to domestic ungulates, and involves differentiation of GE from LE followed by radial development of coiled, tubular glands through endometrial stroma. This pattern of endometrial development is distinct from gland genesis in uteri of adult women and primates, where endometrial glands develop adluminally from the basalis during the proliferative phase after menses and possibly from the stroma.

The human conceptus undergoes interstitial implantation, beginning around day 7 post-fertilization and being complete by days 10 to 12 (see (Burton et al., 2011, Red-Horse et al., 2004, Wooding and Burton, 2008)). When the trophectoderm adheres to the uterine surface it undergoes transformation into syncytiotrophoblast, projections of which penetrate between the uterine epithelial cells into the underlying stroma. By a combination of invasion and most likely proliferation of the surrounding stromal cells, the conceptus becomes encapsulated within the superficial endometrium, with the uterine epithelium regrowing over the implantation site. The endometrium has a high density of uterine glands with approximately 15 openings per $\mathrm{mm}^{2}$ of uterine surface in the non-pregnant state. As the mantle of syncytiotrophoblast enlarges, it encircles and erodes 
into the necks of the glands. Consequently, connections between the lumens of glands and the developing intervillous space of the placenta can be observed as early as day 17 post-fertilization (Hamilton and Gladstone, 1942), and those connections persist throughout the first trimester (Burton et al., 2002).

\section{Uterine gland secretions in humans}

Uterine gland secretions include AA, ions, carbohydrates (glucose), lipids, proteins (cytokines, enzymes, hormones, growth factors, proteases and their inhibitors, transporters, etc.) and likely other substances in the human uterus (Hannan et al., 2010, Hempstock et al., 2004, Kane et al., 1997, Salamonsen et al., 2007, Vilella et al., 2013). They are presumed to be important mediators of uterine receptivity, blastocystimplantation (trophoblastattachment, growth, and invasion), stromal cell decidualization and conceptus growth in humans (Burton et al., 2007, Burton et al., 2011, Cha et al., 2012, Salamonsen et al., 2007). Deficient glandular activity, usually described as a "secretory phase defect", is hypothesized to be an underlying cause of early pregnancy failure in humans (Burton et al., 2007, Dimitriadis et al., 2006), and recent proteomic studies using mass spectrometry found that proteins in the ULF of fertile women change during the menstrual cycle and are altered in ULF from fertile as compared to infertile women (Boomsma et al., 2009, Hannan et al., 2011, Hannan et al., 2010). In women, decidualization is initiated during the mid-late secretory phase by progesterone, independent of the presence of an implanting blastocyst, however the decidua of pregnancy is only formed following blastocyst implantation. Thus, paracrine crosstalk between the GE and stroma may be needed to establish a receptive endometrium and stromal cell decidualization that is important for blastocyst implantation in humans (Koot et al., 2012).

\section{Uterine gland secretions and conceptus nutrition during the first trimester}

In addition to a primary role in blastocyst implantation and perhaps stromal cell decidualization, evidence over the past 10 years provides support for the idea that uterine glands represent an important source of nutrients for the conceptus during the first trimester (Burton et al., 2007, Burton et al., 2011, Hempstock et al., 2004). Histotrophic nutrition can be defined as the provision of nutrients through secretions from the oviductal and uterine glands, and it represents the initial form of nutrition for the conceptus in all species, prior to the establishment of the placenta (Wooding and Burton, 2008). Evidence that the glands may act as a source of nutrition for the human embryo is provided by the observation that the syncytiotrophoblast covering the surfaces of villi facing the endometrium contain accumulations of glycogen (Burton etal., 2002). These accumulations are greatest at the materno-fetal interface, suggesting a concentration dependent uptake by the trophoblast. In addition, during the first trimester the syncytiotrophoblast was shown to phagocytize maternal glycoproteins, including glycodelin A (Burton et al., 2002). Since the glycodelin AmRNA is not detected in placental tissues (Seppala et al., 1992), the presence of vesicles immunoreactive for the glycoprotein within the syncytiotrophoblast confirms uptake.

The importance of the glands during the first trimester has only really been appreciated since it has been recognized that the maternal arterial circulation to the placenta is not fully established until 10 to 12 weeks of pregnancy (Burton et al., 2011, Jauniaux et al., 2003). Although the invading syncytiotrophoblast erodes into the sub-mucosal capillary network, the spiral arteries do not penetrate into the superficial third of the endometrium. Thus, the conceptus has to enlarge considerably before it makes contact with their tips. When the conceptus does break into the arteries, large quantities of endovascular trophoblast migrate down the lumens of the vessels and act as plugs and prevent any blood flow (Burton et al., 1999). Normally, the plugs dissipate towards the end of the first trimester, and it is only then that moving echoes indicative of significant flow can be detected within the intervillous space on ultrasound (Jauniaux et al., 2000). Prior to this time, the intervillous space is filled with a clear fluid that is most likely derived from secretions of the uterine glands. Consequently, the relationship is equivalent to that in the horse or the sheep, except that uterine gland secretions are intraplacental rather than into the uterine luminal fluid (Burton et al., 2011).

\section{Conclusion}

Uterine glands and their secretions have important biological roles in mammalian pregnancy. Some of the cellular events and molecular pathways involved in uterine gland development and function have been identified through gene expression studies and genetically engineered mouse models. However, a significant gap in our knowledge of how the glands function to support early pregnancy events remains. A comprehensive understanding of their biological roles in blastocyst/conceptus growth and implantation, uterine receptivity, and uterine decidualization is needed to generate new knowledge essential for understanding implantation failure and recurrent pregnancy loss and to improve pregnancy rates in women and domestic animals.

\section{Acknowledgement}

The authors wish to thank the Spencer laboratory trainees, collaborators and colleagues who contributed to work highlighted in this manuscript. We apologize for omission of many relevant references due to space limitations. Work in this manuscript was supported, in part, by the United States Department of Agriculture National Institute of Food and Agriculture and the Eunice Kennedy Shriver National Institute of Child Health and Human Development of the National Institutes of Health.

\section{References}

AMOROSO, E.C. (1952). Placentation. In Marshall's Physiology of Reproduction, vol. 2 (ed. PARKS, A. S.). Longmans, Grene and Co., Ltd., London.

ANG, S.L. and ROSSANT, J. (1994). HNF-3 beta is essential for node and notochord formation in mouse development. Cell 78: 561-574.

ARNAUD, E., ZENKER, J., DE PREUX CHARLES, A.S., STENDEL, C., ROOS, A., MEDARD, J.J., TRICAUD, N., KLEINE, H., LUSCHER, B., WEIS, J. et al., (2009). SH3TC2/KIAA1985 protein is required for proper myelination and the integrity of the node of Ranvier in the peripheral nervous system. Proc Natl Acad Sci USA U 106: 17528-17533

BANY, B.M. and CROSS, J.C. (2006). Post-implantation mouse conceptuses produce paracrine signals that regulate the uterine endometrium undergoing decidualization. Dev Biol 294: 445-456.

BARTOL, F.F., WILEY, A.A., COLEMAN, D.A., WOLFE, D.F. and RIDDELL, M.G. (1988a). Ovine uterine morphogenesis: effects of age and progestin administration and withdrawal on neonatal endometrial development and DNA synthesis. J Anim Sci 66: 3000-3009.

BARTOL, F.F., WILEY, A.A., FLOYD, J.G., OTT, T.L., BAZER, F.W., GRAY, C.A. and SPENCER, T.E. (1999). Uterine differentiation as a foundation for subsequent fertility. J Reprod Fertil Supp/ 54: 287-302. 
ARTOL, F.F., WILEY, A.A. and GOODLETT, D.R. (1988b). Ovine uterine morphogenesis: histochemical aspects of endometrial development in the fetus and neonate. J Anim Sci 66: 1303-1313.

BAZER, F.W. (1975). Uterine protein secretions: Relationship to development of the conceptus. J Anim Sci 41: 1376-1382.

BAZER, F.W., WU, G., SPENCER, T.E., JOHNSON, G.A., BURGHARDT, R.C. and BAYLESS, K. (2010). Novel pathways for implantation and establishment and maintenance of pregnancy in mammals. Mol Hum Reprod 16: 135-152.

BHATT, H., BRUNET, L.J. and STEWART, C.L. (1991). Uterine expression of leukemia inhibitory factor coincides with the onset of blastocyst implantation. Proc Natl Acad Sci USA 88: 11408-11412.

BIGSBY, R.M. and CUNHA, G.R. (1985). Effects of progestins and glucocorticoids on deoxyribonucleic acid synthesis in the uterus of the neonatal mouse. Endocrinology 117: 2520-2526

BOOMSMA, C.M., KAVELAARS, A., EIJKEMANS, M.J., LENTJES, E.G., FAUSER, B.C., HEIJNEN, C.J. and MACKLON, N.S. (2009). Endometrial secretion analysis identifies a cytokine profile predictive of pregnancy in IVF. Hum Reprod 24: 1427-1435.

BURTON, G.J., JAUNIAUX, E. and CHARNOCK-JONES, D.S. (2007). Human Early Placental Development: Potential Roles of the Endometrial Glands. Placenta 28: S64-S69.

BURTON, G.J., JAUNIAUX, E. and WATSON, A.L. (1999). Maternal arterial connections to the placental intervillous space during the first trimester of human pregnancy: the Boyd collection revisited. Am J Obstet Gynecol 181: 718-724.

BURTON, G.J., SCIOSCIA, M. and RADEMACHER, T.W. (2011). Endometrial secretions: creating a stimulatory microenvironment within the human early placenta and implications for the aetiopathogenesis of preeclampsia. J Reprod Immunol 89: 118-125.

BURTON, G.J., WATSON, A.L., HEMPSTOCK, J., SKEPPER, J.N. and JAUNIAUX, E. (2002). Uterine glands provide histiotrophic nutrition for the human fetus during the first trimester of pregnancy. J. Clin Endocrinol. Metab. 87: 2954-2959.

CHA, J., SUN, X. and DEY, S.K. (2012). Mechanisms of implantation: strategies for successful pregnancy. Nat Med 18: 1754-1767.

CHAKRABORTY, I., DAS, S.K., WANG, J. and DEY, S.K. (1996). Developmental expression of the cyclo-oxygenase-1 and cyclo-oxygenase-2 genes in the periimplantation mouse uterus and their differential regulation by the blastocyst and ovarian steroids. J Mol Endocrinol 16: 107-122.

CHEN, J.R., CHENG, J.G., SHATZER, T., SEWELL, L., HERNANDEZ, L. and STEWART, C.L. (2000). Leukemia inhibitory factor can substitute for nidatory estrogen and is essential to inducing a receptive uterus for implantation but is not essential for subsequent embryogenesis. Endocrinology 141: 4365-4372.

CHEN, S.C., MEHRAD, B., DENG, J.C., VASSILEVA, G., MANFRA, D.J., COOK, D.N., WIEKOWSKI, M.T., ZLOTNIK, A., STANDIFORD, T.J. and LIRA, S.A. (2001). Impaired pulmonary host defense in mice lacking expression of the CXC chemokine lungkine. J Immunol 166: 3362-3368.

CHEN, W., HAN, B.C., WANG, R.C., XIONG, G.F. and PENG, J.P. (2010). Role of secretory protease inhibitor SPINK3 in mouse uterus during early pregnancy. Cell Tissue Res 341: 441-451.

CLAUSEN, B.E., BURKHARDT, C., REITH, W., RENKAWITZ, R. and FORSTER, I. (1999). Conditional gene targeting in macrophages and granulocytes using LysMcre mice. Transgenic Res 8: 265-277.

COOKE, P.S., EKMAN, G.C., KAUR, J., DAVILA, J., BAGCHI, I.C., CLARK, S.G., DZIUK, P.J., HAYASHI, K. and BARTOL, F.F. (2012). Brief exposure to progesterone during a critical neonatal window prevents uterine gland formation in mice. Biol Reprod 86: 63.

COOKE, P.S., SPENCER, T.E., BARTOL, F.F. and HAYASHI, K. (2013). Uterine glands: development, function and experimental model systems. Mol Hum Reprod 19: 547-558.

DAIKOKU, T., CHA, J., SUN, X., TRANGUCH, S., XIE, H., FUJITA, T., HIROTA, Y., LYDON, J., DEMAYO, F., MAXSON, R. et al., (2011). Conditional deletion of MsX homeobox genes in the uterus inhibits blastocyst implantation by altering uterine receptivity. Dev. Cell 21: 1014-1025.

DAIKOKU, T., TRANGUCH, S., FRIEDMAN, D.B., DAS, S.K., SMITH, D.F. and DEY, S.K. (2005). Proteomic Analysis Identifies Immunophilin FK506 Binding Protein 4 (FKBP52) as a Downstream Target of Hoxa10 in the Periimplantation Mouse Uterus. Mol Endocrinol 19: 683-697.
DIAO, H., XIAO, S., CUI, J., CHUN, J., XU, Y. and YE, X. (2010). Progesterone receptor-mediated up-regulation of transthyretin in preimplantation mouse uterus. Fertil Steril 93: 2750-2753.

DIMITRIADIS, E., STOIKOS, C., STAFFORD-BELL, M., CLARK, I., PAIVA, P., KOVACS, G. and SALAMONSEN, L.A. (2006). Interleukin-11, IL-11 receptoralpha and leukemia inhibitory factor are dysregulated in endometrium of infertile women with endometriosis during the implantation window. J. Reprod. Immunol. 69:53-64.

DIMITRIADIS, E., WHITE, C.A., JONES, R.L. and SALAMONSEN, L.A. (2005). Cytokines, chemokines and growth factors in endometrium related to implantation. Hum Reprod Update 11: 613-630.

DISKIN, M.G. and MORRIS, D.G. (2008). Embryonic and early foetal losses in cattle and other ruminants. Reprod Domest Anim 43 Suppl 2: 260-267.

DORNIAK, P., BAZER, F.W. and SPENCER, T.E. (2013). PHYSIOLOGY AND ENDOCRINOLOGY SYMPOSIUM: Biological role of interferon tau in endometrial function and conceptus elongation. J Anim Sci 91: 1627-1638.

DUNLAP, K.A., FILANT, J., HAYASHI, K., RUCKER, E.B., 3RD, SONG, G., DENG, J.M., BEHRINGER, R.R., DEMAYO, F.J., LYDON, J., JEONG, J.W. et al., (2011). Postnatal deletion of wnt7a inhibits uterine gland morphogenesis and compromises adult fertility in mice. Biol Reprod 85: 386-396.

EPISKOPOU, V., MAEDA, S., NISHIGUCHI, S., SHIMADA, K., GAITANARIS, G.A., GOTTESMAN, M.E. and ROBERTSON, E.J. (1993). Disruption of the transthyretin gene results in mice with depressed levels of plasma retinol and thyroid hormone. Proc Natl Acad Sci USA 90: 2375-2379.

EVANS, G.E., MARTINEZ-CONEJERO, J.A., PHILLIPSON, G.T., SIMON, C., MCNOE, L.A., SYKES, P.H., HORCAJADAS, J.A., LAM, E.Y., PRINT, C.G., SIN, I.L. et al., (2012). Gene and protein expression signature of endometrial glandular and stromal compartments during the window of implantation. Fertil Steril 97: 1365-73 e1-2.

FILANT, J., LYDON, J.P. and SPENCER, T.E. (2013). Integrated chromatin immunoprecipitation sequencing and microarray analysis identifies FOXA2 target genes in the glands of the mouse uterus. FASEB J. 28: 230-243.

FILANT, J. and SPENCER, T.E. (2013a). Cell-specific transcriptional profiling reveals candidate mechanisms regulating development and function of uterine epithelia in mice. Biol Reprod 89: 86.

FILANT, J. and SPENCER, T.E. (2013b). Endometrial glands are essential for blastocyst implantation and decidualization in the mouse uterus. Biol Reprod 88: 93.

FILANT, J., ZHOU, H. and SPENCER, T.E. (2012). Progesterone inhibits uterine gland development in the neonatal mouse uterus. Biol Reprod 86: 146.

FORDE, N. and LONERGAN, P. (2012). Transcriptomic analysis of the bovine endometrium: What is required to establish uterine receptivity to implantation in cattle? J Reprod Dev 58: 189-195.

FRANCO, H.L., DAI, D., LEE, K.Y., RUBEL, C.A., ROOP, D., BOERBOOM, D., JEONG, J.W., LYDON, J.P., BAGCHI, I.C., BAGCHI, M.K. et al., (2011). WNT4 is a key regulator of normal postnatal uterine development and progesterone signaling during embryo implantation and decidualization in the mouse. FASEB J. 25: 1176-1187.

FRANCO, H.L., LEE, K.Y., RUBEL, C.A., CREIGHTON, C.J., WHITE, L.D., BROADDUS, R.R., LEWIS, M.T., LYDON, J.P., JEONG, J.W. and DEMAYO, F.J. (2010). Constitutive activation of smoothened leads to female infertility and altered uterine differentiation in the mouse. Biol Reprod 82: 991-999.

GONZALEZ, I.M., MARTIN, P.M., BURDSAL, C., SLOAN, J.L., MAGER, S., HARRIS, T. and SUTHERLAND, A.E. (2012). Leucine and arginine regulate trophoblast motility through mTOR-dependent and independent pathways in the preimplantation mouse embryo. Dev Biol 361: 286-300.

GRAY, C.A., BARTOL, F.F., TARLETON, B.J., WILEY, A.A., JOHNSON, G.A., BAZER, F.W. and SPENCER, T.E. (2001a). Developmental biology of uterine glands. Biol Reprod 65: 1311-1323

GRAY, C.A., BARTOL, F.F., TAYLOR, K.M., WILEY, A.A., RAMSEY, W.S., OTT, T.L., BAZER, F.W. and SPENCER, T.E. (2000a). Ovine uterine gland knock-out model: effects of gland ablation on the estrous cycle. Biol Reprod 62: 448-456.

GRAY, C.A., BAZER, F.W. and SPENCER, T.E. (2001b). Effects of neonatal progestin exposure on female reproductive tract structure and function in the adult ewe. Biol Reprod 64: 797-804.

GRAY, C.A., BURGHARDT, R.C., JOHNSON, G.A., BAZER, F.W. and SPENCER, T.E. (2002). Evidence that absence of endometrial gland secretions in uterine gland knockout ewes compromises conceptus survival and elongation. Reproduction 124: 289-300. 
GRAY, C.A., TAYLOR, K.M., BAZER, F.W. and SPENCER, T.E. (2000b). Mechanisms regulating norgestomet inhibition of endometrial gland morphogenesis in the neonatal ovine uterus. Mol Reprod Dev 57: 67-78.

GRAY, C.A., TAYLOR, K.M., RAMSEY, W.S., HILL, J.R., BAZER, F.W., BARTOL, F.F. and SPENCER, T.E. (2001C). Endometrial glands are required for preimplantation conceptus elongation and survival. Biol Reprod 64: 1608-1613.

GROSS, G.A., IMAMURA, T., LUEDKE, C., VOGT, S.K., OLSON, L.M., NELSON, D.M., SADOVSKY, Y. and MUGLIA, L.J. (1998). Opposing actions of prostaglandins and oxytocin determine the onset of murine labor. Proc Natl Acad Sci USA 95: 11875-11879.

GUILLOMOT, M. (1995). Cellular interactions during implantation in domestic ruminants. J Reprod Fertil Suppl 49: 39-51.

HAMILTON, W.J. and GLADSTONE, R.J. (1942). A presomite human embryo (Shaw): the implantation. J Anat 76: 187-203.

HANNAN, N.J., PAIVA, P., MEEHAN, K.L., ROMBAUTS, L.J., GARDNER, D.K. and SALAMONSEN, L.A. (2011). Analysis of fertility-related soluble mediators in human uterine fluid identifies VEGF as a key regulator of embryo implantation. Endocrinology 152: 4948-4956.

HANNAN, N.J., STEPHENS, A.N., RAINCZUK, A., HINCKS, C., ROMBAUTS, L.J. and SALAMONSEN, L.A. (2010). 2D-DiGE analysis of the human endometrial secretome reveals differences between receptive and nonreceptive states in fertile and infertile women. J Proteome Res 9: 6256-6264.

HARRIS, S.E., GOPICHANDRAN, N., PICTON, H.M., LEESE, H.J. and ORSI, N.M. (2005). Nutrient concentrations in murine follicular fluid and the female reproductive tract. Theriogenology 64: 992-1006.

HEMPSTOCK, J., CINDROVA-DAVIES, T., JAUNIAUX, E. and BURTON, G. (2004). Endometrial glands as a source of nutrients, growth factors and cytokines during the first trimester of human pregnancy: Amorphological and immunohistochemical study. Reprod. Biol. Endocrinol. 2: 58.

HUE, I., DEGRELLE, S.A. and TURENNE, N. (2012). Conceptus elongation in cattle: genes, models and questions. Anim Reprod Sci 134: 19-28.

JAUNIAUX, E., GULBIS, B. and BURTON, G.J. (2003). Physiological implications of the materno-fetal oxygen gradient in human early pregnancy. Reprod Biomed Online 7: 250-253.

JAUNIAUX, E., WATSON, A.L., HEMPSTOCK, J., BAO, Y.P., SKEPPER, J.N. and BURTON, G.J. (2000). Onset of maternal arterial blood flow and placental oxidative stress. A possible factor in human early pregnancy failure. Am J Pathol 157: 2111-2122.

JEONG, J.W., KWAK, I., LEE, K.Y., KIM, T.H., LARGE, M.J., STEWART, C.L., KAESTNER, K.H., LYDON, J.P. and DEMAYO, F.J. (2010). Foxa2 is essential for mouse endometrial gland development and fertility. Biol Reprod 83: 396-403.

JEONG, J.W., LEE, H.S., FRANCO, H.L., BROADDUS, R.R., TAKETO, M.M., TSAI, S.Y., LYDON, J.P. and DEMAYO, F.J. (2009). beta-catenin mediates glandular formation and dysregulation of beta-catenin induces hyperplasia formation in the murine uterus. Oncogene 28: 31-40.

JEONG, J.W., LEE, K.Y., LYDON, J.P. and DEMAYO, F.J. (2006). Steroid hormone regulation of Clca3 expression in the murine uterus. $J$ Endocrinol 189: 473-484.

KANE, M.T., MORGAN, P.M. and COONAN, C. (1997). Peptide growth factors and preimplantation development. Hum Reprod Update 3: 137-157.

KASHIWAGI, A., DIGIROLAMO, C.M., KANDA, Y., NIIKURA, Y., ESMON, C.T., HANSEN, T.R., SHIODA, T. and PRU, J.K. (2007). The postimplantation embryo differentially regulates endometrial gene expression and decidualization. Endocrinology 148: 4173-4184.

KOCH, J.M., RAMADOSS, J. and MAGNESS, R.R. (2010). Proteomic profile of uterine luminal fluid from early pregnant ewes. J Proteome Res 9: 3878-3885.

KOOT, Y.E., TEKLENBURG, G., SALKER, M.S., BROSENS, J.J. and MACKLON, N.S. (2012). Molecular aspects of implantation failure. Biochim Biophys Acta 1822: 1943-1950.

LEE, K., JEONG, J., KWAK, I., YU, C.T., LANSKE, B., SOEGIARTO, D.W., TOFTGARD, R., TSAI, M.J., TSAI, S., LYDON, J.P. et al., (2006). Indian hedgehog is a major mediator of progesterone signaling in the mouse uterus. Nat Genet38: 1204-1209.

LEJEUNE, B., VAN HOECK, J. and LEROY, F. (1981). Transmitter role of the luminal uterine epithelium in the induction of decidualization in rats. $J$ Reprod Fertil 61: 235-240.

LIM, H., GUPTA, R.A., MA, W.G., PARIA, B.C., MOLLER, D.E., MORROW, J.D., DUBOIS, R.N., TRZASKOS, J.M. and DEY, S.K. (1999). Cyclo-oxygenase-2-derived prostacyclin mediates embryo implantation in the mouse via PPARdelta. Genes Dev 13: 1561-1574.

LIM, H., PARIA, B.C., DAS, S.K., DINCHUK, J.E., LANGENBACH, R., TRZASKOS, J.M. and DEY, S.K. (1997). Multiple female reproductive failures in cyclooxygenase 2-deficient mice. Cell 91: 197-208.

MAEDA, N., HAGIHARA, H., NAKATA, Y., HILLER, S., WILDER, J. and REDDICK, R. (2000). Aortic wall damage in mice unable to synthesize ascorbic acid. Proc Natl Acad Sci USA 97: 841-846.

MARTIN, P.M., SUTHERLAND, A.E. and VAN WINKLE, L.J. (2003). Amino acid transport regulates blastocyst implantation. Biol Reprod 69: 1101-1108.

MCMASTER, M.T., TENG, C.T., DEY, S.K. and ANDREWS, G.K. (1992). Lactoferrin in the mouse uterus: analyses of the preimplantation period and regulation by ovarian steroids. Mol Endocrinol 6: 101-111.

NEEDHAM, J. (1959). A History of Embryology. Cambridge University Press, London.

NI, H., DING, N.Z., HARPER, M.J. and YANG, Z.M. (2002). Expression of leukemia inhibitory factor receptor and gp130 in mouse uterus during early pregnancy. Mol Reprod Dev 63: 143-150.

NIKLAUS, A.L. and POLLARD, J.W. (2006). Mining the Mouse Transcriptome of Receptive Endometrium Reveals Distinct Molecular Signatures for the Luminal and Glandular Epithelium. Endocrinology 147: 3375-3390.

O'SULLIVAN, C.M., LIU, S.Y., KARPINKA, J.B. and RANCOURT, D.E. (2002). Embryonic hatching enzyme strypsin/ISP1 is expressed with ISP2 in endometrial glands during implantation. Mol Reprod Dev 62: 328-334.

O'SULLIVAN, C.M., LIU, S.Y., RANCOURT, S.L. and RANCOURT, D.E. (2001) Regulation of the strypsin-related proteinase ISP2 by progesterone in endometrial gland epithelium during implantation in mice. Reproduction 122: 235-244.

OGASAWARA, Y., OKAMOTO, S., KITAMURA, Y. and MATSUMOTO, K. (1983). Proliferative pattern of uterine cells from birth to adulthood in intact, neonatally castrated, and/or adrenalectomized mice, assayed by incorporation of [125I] iododeoxyuridine. Endocrinology 113: 582-587.

OHMURAYA, M., HIROTA, M., ARAKI, M., MIZUSHIMA, N., MATSUI, M., MIZUMOTO, T., HARUNA, K., KUME, S., TAKEYA, M., OGAWA, M. et al., (2005). Autophagic cell death of pancreatic acinar cells in serine protease inhibitor Kazal type 3-deficient mice. Gastroenterology 129: 696-705.

PAIVA, P., MENKHORST, E., SALAMONSEN, L. and DIMITRIADIS, E. (2009). Leukemia inhibitory factor and interleukin-11: critical regulators in the establishment of pregnancy. Cytokine Growth Factor Rev 20: 319-328.

PARIA, B.C., ZHAO, X., DAS, S.K., DEY, S.K. and YOSHINAGA, K. (1999). Zonula occludens- 1 and $\mathrm{E}$-cadherin are coordinately expressed in the mouse uterus with the initiation of implantation and decidualization. Dev Biol 208: 488-501.

RAMATHAL, C.Y., BAGCHI, I.C., TAYLOR, R.N. and BAGCHI, M.K. (2010). Endometrial decidualization: of mice and men. Sem. Reprod. Med. 28: 17-26.

REARDON, S.N., KING, M.L., MACLEAN, J.A., 2ND, MANN, J.L., DEMAYO, F.J., LYDON, J.P. and HAYASHI, K. (2012). CDH1 is essential for endometrial differentiation, gland development, and adult function in the mouse uterus. Biol Reprod 86: 1-10

RED-HORSE, K., ZHOU, Y., GENBACEV, O., PRAKOBPHOL, A., FOULK, R., MCMASTER, M. and FISHER, S.J. (2004). Trophoblast differentiation during embryo implantation and formation of the maternal-fetal interface. J. Clin. Invest. 114: 744-754.

ROBICHAUD, A., TUCK, S.A., KARGMAN, S., TAM, J., WONG, E., ABRAMOVITZ, M., MORTIMER, J.R., BURSTON, H.E., MASSON, P., HIROTA, J. et al., (2005). Gob-5 is not essential for mucus overproduction in preclinical murine models of allergic asthma. Am J Respir Cell Mol Biol 33: 303-314.

SALAMONSEN, L.A., HANNAN, N.J. and DIMITRIADIS, E. (2007). Cytokines and chemokines during human embryo implantation: roles in implantation and early placentation. Sem. Reprod. Med. 25: 437-444.

SATOKATA, I., MA, L., OHSHIMA, H., BEI, M., WOO, I., NISHIZAWA, K., MAEDA T., TAKANO, Y., UCHIYAMA, M., HEANEY, S. et al., (2000). Msx2 deficiency in mice causes pleiotropic defects in bone growth and ectodermal organ formation. Nat Genet 24: 391-395.

SCHMITZ, J.M., MCCRACKEN, V.J., DIMMITT, R.A. and LORENZ, R.G. (2007). Expression of CXCL15 (Lungkine) in murine gastrointestinal, urogenital, and endocrine organs. J Histochem Cytochem 55: 515-524.

SEPPALA, M., JULKUNEN, M., RIITTINEN, L. and KOISTINEN, R. (1992). Endometrial proteins: a reappraisal. Hum Reprod 7 Suppl 1: 31-38. 


\section{J. Filant et al.}

SHELTON, D.N., FORNALIK, H., NEFF, T., PARK, S.Y., BENDER, D., DEGEEST, K., LIU, X., XIE, W., MEYERHOLZ, D.K., ENGELHARDT, J.F. et al., (2012). The role of LEF1 in endometrial gland formation and carcinogenesis. PLoS One 7: e40312.

SHUYA, L.L., MENKHORST, E.M., YAP, J., LI, P., LANE, N. and DIMITRIADIS, E. (2011). Leukemia inhibitory factor enhances endometrial stromal cell decidualization in humans and mice. PLoS One 6: e25288.

SONG, H., LIM, H., DAS, S.K., PARIA, B.C. and DEY, S.K. (2000). Dysregulation of EGF family of growth factors and COX-2 in the uterus during the preattachment and attachment reactions of the blastocyst with the luminal epithelium correlates with implantation failure in LIF-deficient mice. Mol Endocrinol 14: 1147-1161.

SOTIRIOU, S., GISPERT, S., CHENG, J., WANG, Y., CHEN, A., HOOGSTRATENMILLER, S., MILLER, G.F., KWON, O., LEVINE, M., GUTTENTAG, S.H. et al., (2002). Ascorbic-acid transporter SIc23a1 is essential for vitamin C transport into the brain and for perinatal survival. Nat Med 8: 514-517.

SPENCER, T.E., DUNLAP, K.A. and FILANT, J. (2012). Comparative developmental biology of the uterus: insights into mechanisms and developmental disruption. Mol. Cell Endocrinol 354: 34-53.

SPENCER, T.E., HAYASHI, K., HU, J. and CARPENTER, K.D. (2005). Comparative developmental biology of the mammalian uterus. Curr Top Dev Biol 68: 85-122.

SPENCER, T.E., JOHNSON, G.A., BAZER, F.W. and BURGHARDT, R.C. (2004). Implantation mechanisms: insights from the sheep. Reproduction 128: 657-668.

SPENCER, T.E., SANDRA, O. and WOLF, E. (2008). Genes involved in conceptusendometrial interactions in ruminants: insights from reductionism and thoughts on holistic approaches. Reproduction 135: 165-179.

STEWART, C.L., KASPAR, P., BRUNET, L.J., BHATT, H., GADI, I., KONTGEN, F. and ABBONDANZO, S.J. (1992). Blastocyst implantation depends on maternal expression of leukaemia inhibitory factor. Nature 359: 76-79.

SUN, X., ZHANG, L., XIE, H., WAN, H., MAGELLA, B., WHITSETT, J.A. and DEY, S.K. (2012). Kruppel-like factor 5 (KLF5) is critical for conferring uterine receptivity to implantation. Proc Natl Acad Sci USA 109: 1145-1150.

SUZUKI, N., NADANO, D., PARIA, B.C., KUPRIYANOV, S., SUGIHARA, K. and FUKUDA, M.N. (2000). Trophinin expression in the mouse uterus coincides with implantation and is hormonally regulated but not induced by implanting blastocysts. Endocrinology 141: 4247-4254.

VILELLA, F., RAMIREZ, L.B. and SIMON, C. (2013). Lipidomics as an emerging tool to predict endometrial receptivity. Fertil Steril 99: 1100-1106.

VON HOFFMAN, G. (1884). Uterine milk. Am. J. Med. Sci. 87: 254-255.

WANG, H. and DEY, S.K. (2006). Roadmap to embryo implantation: clues from mouse models. Nat Rev Genet 7: 185-199.

WARD, P.P., MENDOZA-MENESES, M., CUNNINGHAM, G.A. and CONNEELY, O.M. (2003). Iron status in mice carrying a targeted disruption of lactoferrin. Mol Cell Biol 23: 178-185.

WETENDORF, M. and DEMAYO, F.J. (2012). The progesterone receptor regulates implantation, decidualization, and glandular development via a complex paracrine signaling network. Mol Cell Endocrinol 357: 108-118.

WOODING, F.B.P. and BURTON, G.J. (2008). Comparative Placentation: Structures, Functions and Evolution. Springer, Berlin.

YOSHIDA, K., TAGA, T., SAITO, M., SUEMATSU, S., KUMANOGOH, A., TANAKA, T., FUJIWARA, H., HIRATA, M., YAMAGAMI, T., NAKAHATA, T. et al., (1996). Targeted disruption of gp130, a common signal transducer for the interleukin 6 family of cytokines, leads to myocardial and hematological disorders. Proc Natl Acad Sci USA 93: 407-411.

ZHANG, S., LIN, H., KONG, S., WANG, S., WANG, H., WANG, H. and ARMANT, D.R. (2013). Physiological and molecular determinants of embryo implantation. Mol. Aspects Med. 34: 939-980.

ZHU, L.J., BAGCHI, M.K. and BAGCHI, I.C. (1998). Attenuation of calcitonin gene expression in pregnant rat uterus leads to a block in embryonic implantation. Endocrinology 139: 330-339. 


\section{Further Related Reading, published previously in the Int. J. Dev. Biol.}

Implantation: molecular basis of embryo-uterine dialogue

B C Paria, H Song and S K Dey

Int. J. Dev. Biol. (2001) 45: 597-605

http://www.intjdevbiol.com/web/paper/11417904

\section{Nuclear reprogramming in zygotes}

Chanchao Lorthongpanich, Davor Solter and Chin Yan Lim

Int. J. Dev. Biol. (2010) 54: 1631-1640

http://www.intjdevbiol.com/web/paper/103201cl

Shear stress regulation of nitric oxide production in uterine and placental artery endothelial cells: experimental studies and hemodynamic models of shear stresses on endothelial cells

Benjamin Sprague, Naomi C. Chesler and Ronald R. Magness

Int. J. Dev. Biol. (2010) 54: 331-339

http://www.intjdevbiol.com/web/paper/082832bs

Endometrial responses to embryonic signals in the primate

Prajna Banerjee and Asgerally T. Fazleabas

Int. J. Dev. Biol. (2010) 54: 295-302

http://www.intjdevbiol.com/web/paper/082829pb

Uteroplacental vascular development and placental function: an update

Lawrence P. Reynolds, Pawel P. Borowicz, Joel S. Caton, Kimberly A. Vonnahme, Justin S. Luther, David S. Buchanan, Shireen A. Hafez, Anna T. Grazul-Bilska and Dale A. Redmer Int. J. Dev. Biol. (2010) 54: 355-365

http://www.intjdevbiol.com/web/paper/082799/r

On the role of placental major histocompatibility complex and decidual leukocytes in implantation and pregnancy success using non-human primate models

Thaddeus G. Golos, Gennadiy I. Bondarenko, Svetlana V. Dambaeva, Edith E. Breburda, and Maureen Durning

Int. J. Dev. Biol. (2010) 54: 431-443

http://www.intjdevbiol.com/web/paper/082797tg

Some historical aspects of understanding placental development, structure and function Lawrence D. Longo and Lawrence P. Reynolds

Int. J. Dev. Biol. (2010) 54: 237-255

http://www.intjdevbiol.com/web/paper/082774ll

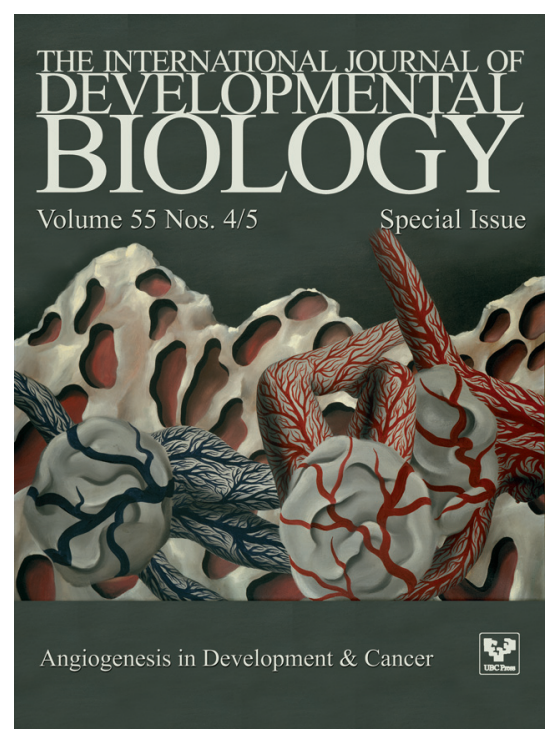

5 yr ISI Impact Factor $(2011)=2.959$
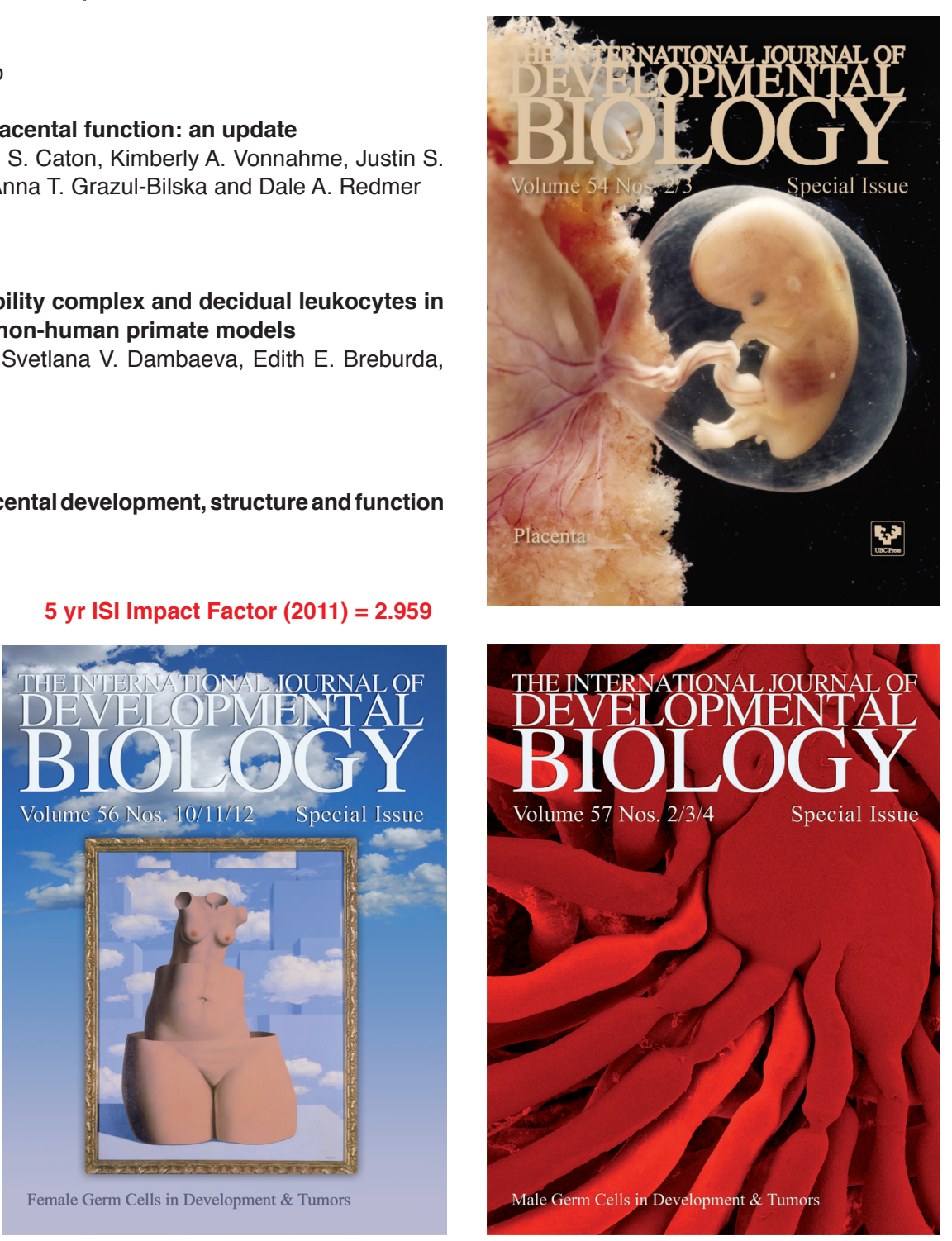